\title{
COMPARATIVE ANALYSIS OF ALTERNATIVE FUELS USED IN ROAD TRANSPORT
}

In recent years, especially alternative fuels have been undergoing significant and rapid development, since the society is aware of the negative impacts of a long term and excessive use of fossil fuels on the environment as well as of the fact that the raw materials are finite. The article shows a new approach to using of alternative fuels in transport in the future. The description introduces both conventional and unconventional fuels. The analysis is focused on the comparison of the fuels in terms of the formation of CO, SO2, NOx and CO2 emissions, as well as their energy performance. In the conclusion the paper outlines the future of automobile propulsion in the context of sustainable development of transport.

Keywords: Fuels, alternative fuels, road transport, automobile.

\section{Introduction}

Currently, mainly combustion engines are used in road transport. The history of combustion engines dates back to the 1970's [1 and 2]. A significant increase in using combustion engines was noted ten years later. The first journey undertaken by a vehicle using combustion engine was realized in 1862. It was a three-track vehicle designed by two German engineers, G. W. Daimler and C. F. Benz, a gas-driven vehicle with a cyclic battery ignition system. The maximum speed of the vehicle was $18 \mathrm{~km} / \mathrm{h}$, with only as many as $100 \mathrm{r} / \mathrm{m}^{-1}$. The chassis frame was made of steel weldment and the engine in the frame was placed horizontally. Its volume was only $954 \mathrm{~cm}^{3}$, with engine power of $2 \mathrm{hp}$ (horse power) [3].

As for alternative fuels, their use is usually based on the principle of combustion or electric engines, for example CNG (Compressed Natural Gas), LPG (Liquefied Petroleum Gas), E85 (bioethanol) or hydrogen, only the composition of combustion mixture is different. Hybrid engines are the combination of combustion and electric engines [4].

\section{Characteristics of conventional fuels}

Petrol is a name used for the fractions of crude oil with the boiling range between $30{ }^{\circ} \mathrm{C}$ and $200{ }^{\circ} \mathrm{C}$. This temperature range is related to the atmospheric air pressure and is determined by various mixture compositions. According to types of use, we distinguish between gasoline, avgas (aviation gasoline) and technical petrol, where the first type is considered the most produced one [5].

Gasoline is the mixture of liquid hydrocarbon, with the boiling range between $30-215{ }^{\circ} \mathrm{C}$ and is intended for the cars equipped with a combustion engine [6]. The specific share of hydrocarbon in gasoline differs depending on its kind, raw materials used and refinery production technology. The basis for further processing is the petrol fraction obtained by the atmospheric distillation. This fraction is regulated by mixing other components in order to get the appropriate octane number, optimum exhaust gas composition etc. [5].

Diesel is a mixture which is composed mainly of paraffinic, cycloparaffinic and aromatic liquid hydrocarbons, with the boiling range between $150-370{ }^{\circ} \mathrm{C}$. This basic mixture is usually modified by additives improving low-temperature fuel properties or using. Diesel serves as the fuel for diesel motors, which gave rise to the designation used for the fuel - diesel known from the designations found on the petrol pumps [7].

Diesel is not a special petroleum fraction during the distillation of crude oil but it is prepared by mixing gas oil and kerosene in order to obtain adequate properties. A necessary step for getting the final properties of diesel is desulphurization since the fractions from the distillation contain quite a large amount of sulphur compounds. One of the diesel components is kerosene, an element important for flashpoint, since unlike petrol, diesel ignites spontaneously in

\footnotetext{
* ${ }^{1}$ Jan Lizbetin, ${ }^{2}$ Ladislav Bartuska, ${ }^{3}$ Aleksandr Rakhmangulov

${ }^{1}$ The Institute of Technology and Business in Ceske Budejovice, Faculty of Technology, Department of Transport and Logistics, Czech Republic ${ }^{2}$ The Institute of Technology and Business in Ceske Budejovice, Faculty of Technology, Department of Transport and Logistics, Czech Republic ${ }^{3}$ Nosov Magnitogorsk State Technical University, Mining Engineering and Transport Institute, Russia

E-mail: lizbetin@mail.vstecb.cz
} 
compression of its volume in space and does not need a spark for ignition.

A disadvantage of diesel is a content of so called heavy shares which cause sedimentation rate and gradual clogging of high-pressure nozzles in engines. In order to prevent this and at the same time to improve the diesel properties, additives such as depressants, detergents, inhibitors or anti-foaming agents are used [8, 9 and 10] Depressants have a significant influence on freezing temperature, a process which is referred to as the "paraffination of diesel". Detergents reduce possible sedimentation which occurs during a long storage of diesel. Inhibitors serve as a protection of friction parts in engines. Anti-foaming agents limit foaming of diesel [11].

\section{Characteristic of alternative fuels}

Nowadays, alternative fuels are considered to be those which replace conventional fuels, such as petrol and diesel. These include also the fuels which are more environmentally friendly. In 1992, the term "alternative fuel" was redefined, covering any fuels of non-oil based origin. This designation can be also used for conventional fuels used in alternative forms. Currently, there are several alternative and reformulated fuels [12 and 13].

Recently, there have been discussions about what type of fuel is the most suitable one for vehicles, since there are limited supplies of gasoline and diesel. LPG, methanol and ethanol seem to reach a deadlock in the future due to their expected further development. Therefore, the best of alternative fuels seems to be natural gas with relatively large reserves, hydrogen and electricity.

The following table (Table 1) gives an overview of alternative fuels used in the present road transport.

Overview of current alternative fuels

Table 1

\begin{tabular}{|l|}
\hline \multicolumn{1}{|c|}{ Substitute for gasoline and diesel oil } \\
\hline Gas \\
\hline $\begin{array}{l}\text { Compressed natural gas (CNG - compressed natural gas) } \\
\text { Liquefied natural gas (LNG - Liquefied Natural Gas) } \\
\text { Liquefied petroleum gas (LPG - Liquefied Petroleum Gas) }\end{array}$ \\
\hline Oxygen fuels \\
\hline $\begin{array}{l}\text { Alcohols (methanol, ethanol) } \\
\text { ethers (MTBE - methyl tert-butyl ether, ETBE - ethyl tert-butyl } \\
\text { ether) }\end{array}$ \\
\hline Vegetable oils and animal fat \\
\hline Electric or hybrid drive \\
\hline Hydrogen \\
\hline
\end{tabular}

Source: [14]

Detailed characteristic of each fuel type is included in [15].

\section{Comparison of alternative fuels}

Data on pollutant emissions resulting from using motor vehicles were obtained from the individual cited sources [16 - 20]. The data are taken from testing laboratories while using combustion engines placed in the laboratories with a constant temperature and pressure. These preconditions are necessary for preventing the distortion of resulting values due to surrounding environment. The combustion unit is equipped with a system enabling easy and fast changes of the individual fuels, such as a removable motor head for spark and diesel combustion [21].

The following graphs show the pollutant emissions given in $\mathrm{g} / \mathrm{km}$ $\left(\mathrm{CO}, \mathrm{SO}_{2}, \mathrm{NO}_{\mathrm{x}}, \mathrm{CO}_{2}\right.$ ), which arise from the combustion of each fuel.

It results from Fig. 1 that the $\mathrm{CO}$ emissions are at the peak during E85 $(0.84 \mathrm{~g} / \mathrm{km})$ and gasoline $(0.76 \mathrm{~g} / \mathrm{km})$ combustion. On the contrary, the lowest emissions occur during CNG $(0.0225 \mathrm{~g} / \mathrm{km})$ combustion. Combusting diesel and LPG produces approximately the same amount of $\mathrm{CO}(0.41 \mathrm{~g} / \mathrm{km})$ emissions.

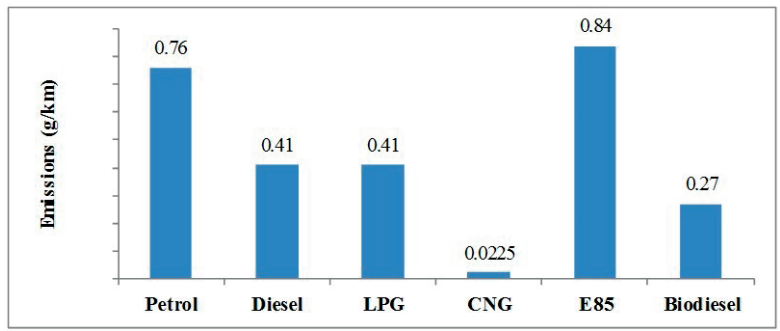

Fig. 1 CO emissions by individual kinds of fuel; source: authors

Figure 2 shows comparison of the sulphur dioxide $\left(\mathrm{SO}_{2}\right)$ emissions produced during the process of combusting various kinds of fuels. The highest $\mathrm{SO}_{2}$ emissions are produced during E85 (0.078 $\mathrm{g} / \mathrm{km}$ ) combustion. Other emission figures are negligible.

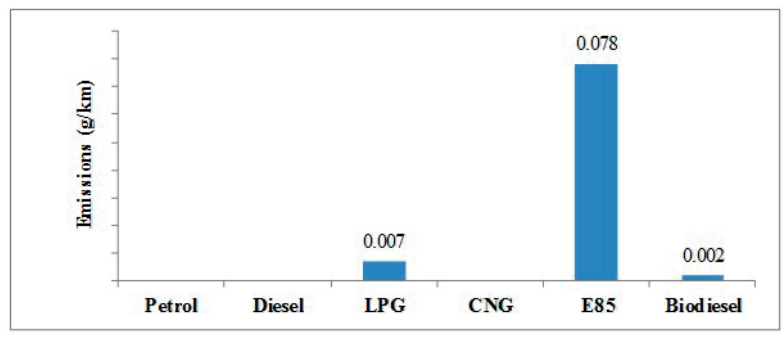

Fig. $2 \mathrm{SO}_{2}$ emissions by individual kinds of fuel; source: authors

Figure 3 shows the amount of nitrogen oxide emissions during combustion. The highest amount of pollutants is produced during CNG $(0.303 \mathrm{~g} / \mathrm{km})$ combustion, while during biodiesel and E85 combustion there is a comparable amount of emissions $(0.079 \mathrm{~g} /$ $\mathrm{km}$ and $0.073 \mathrm{~g} / \mathrm{km}$ ) produced. The lowest amount of nitrogen oxide pollutants is produced during the petrol, diesel and LPG combustion. 


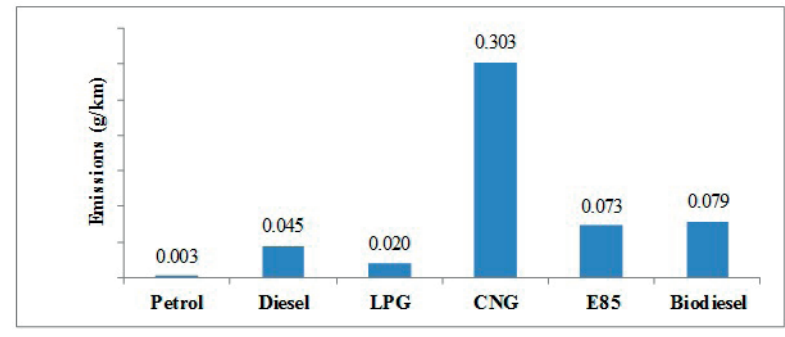

Fig. $3 \mathrm{NO}_{x}$ emissions by individual types of fuel; source: authors

Figure 4 compares the amount of $\mathrm{CO}_{2}$ emissions. The values obtained by combusting petrol, diesel, LPG and E85 are more or less the same. Much lower emissions are produced during CNG combustion $(99.75 \mathrm{~g} / \mathrm{km}$ carbon dioxide). The most environmentally friendly fuel in terms of $\mathrm{CO}_{2}$ emissions seems to be biodiesel (only $0.039 \mathrm{~g} / \mathrm{km}$ of $\mathrm{CO}_{2}$ emissions).

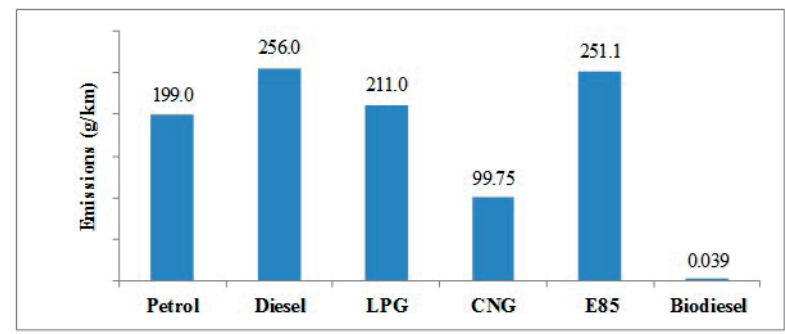

Fig. $4 \mathrm{CO}_{2}$ emissions by individual kinds of fuel; source: authors

Figure 5 shows the individual fuels in terms of energy efficiency. From the six chosen fuels the lowest calorific value is for E85 (28.60 $\mathrm{MJ} / \mathrm{kg}$ ), while the highest one is for CNG (55 MJ $/ \mathrm{kg}$ ). Petrol, diesel, LPG (propane and butane) and biodiesel values are about the same.

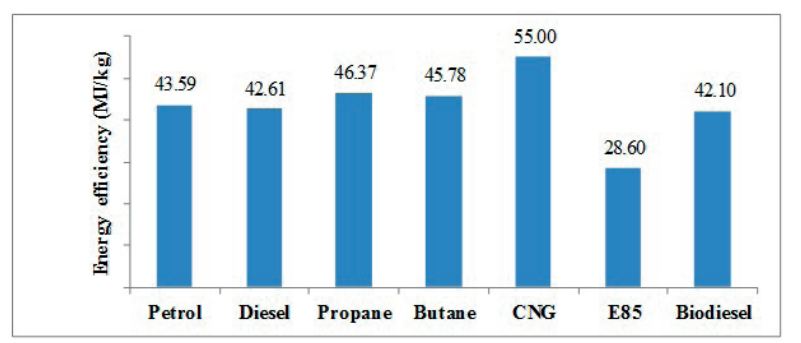

Fig. 5 Energy efficiency by individual kinds of fuels; source: authors

\section{Conclusion}

By comparing individual fuels from an economic point of view it might be concluded that for the users, more preferable (cheaper) ones are those that do not require retrofitting of a storage or standalone unit (e.g. petrol, diesel, ethanol or biodiesel). From this point of view, ethanol combustion is definitely the most preferable one, as it can be mixed with gasoline in any ratio. The only investment required is the mounting of the unit for the combustion of the mixture. As for the fuel consumption, LPG is the most economical one due the lowest price of this fuel in comparison with other fuels [22 - 23].

By comparing the advantages and disadvantages of selected fuels, several possible conclusions can be drawn, depending on the individual needs of the users. From the authors' points of view, $\mathrm{CNG}$ or ethanol are the most preferable ones. As for CNG, the main advantage is its low consumption and price while in the case of ethanol the major advantage is the possibility of refuelling this mixture into one tank together with petrol [24].

In the late 1950s, the geologist and geophysicist Marion King Hubbert published his theory of peak oil [25], in which he predicted the culmination of oil production approximately in the 1970s. Subsequently, he predicted a gradual decline of oil production volume, and the end of oil production due to exhaustion of fossil resources in the years 2090 - 2110. For this reason it is inevitable to find alternative ways of automobile propulsion. Natural gas in any form does not guarantee sustainability in transport, since it is a fossil fuel. The future of transport and automobile propulsion is in renewable resources, especially in hydrogen propulsion. The utilization of hydrogen can be practically unlimited. Another benefit of hydrogen is environmental friendliness because hydrogen combustion releases only pure water. Therefore, hydrogen fuel can be considered as the most advantageous alternative fuel of the future.

\section{References}

[1] HOLESA, L., HRUDKAY, K.: The Impact of Selected Factors of Utility Motor Vehicles Operation Conditions on the Economy Driving, Communications - Scientific Letters of the University of Zilina, No. 3, 2015, ISSN 1335-4205.

[2] TOMASIKOVA, M., BRUMERCIK, F., NIEOCZYM, A.: Vehicle Simulation Model Criterion, Logi-Scientific J. on Transport and Logistics, vol. 6, No. 1, 2015, 130-135, ISSN 1804-3216.

[3] REMEK, B.: Automobile and its Combustion Engine: Historical Development, $1^{\text {st }}$ ed. (in Czech), Praha : Grada, 2012, 159 p. ISBN 978-80-247-3538-2. 
[4] Mitropoulos, L. K., PREVEdouros, P. D.: Life Cycle Emissions and Cost Model for Urban Light Duty Vehicles, Transportation Research Part D: Transport and Environment, 41, 2015, 147-159, ISSN 13619209.

[5] ROUBICEK, V., RABL, V.: Petroleum Technology: Alternative Fuels, $1^{\text {st }}$ ed. (in Czech), Ostrava : VSB - Technicka univerzita, Fakulta metalurgie a materialoveho inzenyrstvi, 2000, 267 p., ISBN 80-7078-690-6.

[6] ZEHNALEK, J.: Chemicals, Fuels, Oils, $1^{\text {st }}$ ed. (in Czech), Brno : Mendelova zemedelska a lesnicka univerzita, 1998, 176 p. ISBN 80-7157314-0.

[7] BLAZEK, J., RABL, V.: Basics of Oil Processing, $1^{\text {st }}$ ed. (in Czech), Praha : Vysoka skola chemicko-technologicka v Praze, 2002, 255 p., ISBN 80-7080-473-4.

[8] SIMKOVA, I., KONECNY, V.: Key Performance Indicators in Logistics and Road Transport, Logi-Scientific J. on Transport and Logistics, vol. 5, No. 2, 2014, 87-96, ISSN 1804-3216.

[9] RIEVAJ, V., STOPKA, O., VRABEL, J., MOKRICKOVA, L., SCHMIDT, C.: The Impact of Air Resistance on the Fuel Consumption in Real Conditions within the Transport Operation, Communications - Scientific Letters of the University of Zilina, No. 2, 2016, ISSN 13354205.

[10] OU, K. S., ZHENG, J., LUO, W. J., LI, X. F., HU, H. S., YANG, J. B., ZHENG, J. Y.: Heat and Mechanical Response Analysis of Composite Compressed Natural Gas Cylinders at Vehicle Fire Scenario, Procedia Engineering, 130, 2015, 1425-1440, ISSN 18777058.

[11] MATEJOVSKY, V.: Automobile Fuels, $1^{\text {st }} e d$. (in Czech), Praha : Grada, 2005, 223 p., ISBN 80-247-0350-5.

[12] HAMMADI, M., IEBBA, M., CAMARGO ROSA, F., VENERI, O., CAPASSO, C., PATALANO, S., COPERTINO, G.: System Approach to the Pre-Design of Electric Propulsion Systems for Road Vehicles, $1^{\text {st }}$ IEEE Intern. Symposium on Systems Engineering, ISSE 2015 - Proc., art. No. 7302762, 2015, 229-236, ISBN: 9781479919208.

[13] DIMITROVA, Z., MARECHAL, F.: Gasoline Hybrid Pneumatic Engine for Efficient Vehicle Powertrain Hybridization, Applied Energy, 151, 2015, 168-177, ISSN 03062619.

[14] MORAVCIK, L.: Alternative Propulsion of Road Vehicles (in Slovak), Doprava a spoje : Zilinska univerzita : Zilina [online]. 20.5.2010, 2010, c. 1, [cit. 2011-04-02]. 〈http://fpedas.uniza.sk/dopravaaspoje/2010/1/moravcik.pdf〉. ISSN 1336-767.

[15] SETKA, O.: Alternative Propulsion in Road and Rail Transport (in Czech), bachelor thesis, Vysoka skola technicka a ekonomicka : Ceske Budejovice, 2015.

[16] HROMADKO, J.: Combustion Engines: A Comprehensive Overview of Issues for All Types of Automotive Technical Schools, $1^{\text {st }}$ ed. (in Czech), Praha : Grada, 2011, 296 p., ISBN 978-80-247-3475-0.

[17] MICHAL, P.: Biogas - Energy from Agriculture (in Czech), Biom.cz [online]. 2005 [cit. 2015-06-25]. http://biom.cz/ upload/6e01d6d4c4835ec93cda508772f3bf6e/bioplyn_energie_ze_zemedelstvi.pdf.

[18] STRAKA, J.: Hydrogen. Periodic Table (in Czech), [online], 2015 [cit. 2015-06-16]. http://www.tabulka.cz/prvky/ukaz.asp?id=1.

[19] TOSOVSKY, J.: ELECTRO-FARMING: The Key to Obtaining very Pure Hydrogen and Cheap Energy (in Czech), Biom.cz [online]. 200202-07 [cit. 2015-06-17]. 〈http://biom.cz/cz/odborne-clanky/electro-farming-klic-k-ziskavani-velmi-cisteho-vodiku-a-levne-energie〉. ISSN 1801-2655.

[20] VLK, F.: Alternative Propulsion of Motor Vehicles, $1^{\text {st }}$ ed. (in Czech), Brno : Frantisek Vlk, 2004, 234 p., ISBN 80-239-1602-5.

[21] GRAEBENER, S., TARNOWSKI, M., GOEHLICH, D.: Commercial Vehicle Drive Train Technology and Topology Pre-Selection, $10^{\text {th }}$ Intern. Conference on Ecological Vehicles and Renewable Energies, EVER 2015, art. No. 7113011, 2015, ISBN 9781467367844.

[22] DORDA, A., NIKOWITZ, M.: Strategy and Instruments for a Successful Implementation of Electromobility in Austria, $28^{\text {th }}$ Intern. Electric Vehicle Symposium and Exhibition, 2015, EVS 2015, 2015, ISBN 9781510809260.

[23] WANG, Y., XING, Z., XU, H., DU, K.: Emission Factors of Air Pollutants from CNG-Gasoline Bi-Fuel Vehicles, Part I. Black carbon, Science of the Total Environment, 572, 2016, 1161-1165, ISSN 00489697.

[24] KHAN, M. I., YASMIN, T., SHAKOOR, A.: International Experience with Compressed Natural Gas (CNG) as Environmental Friendly Fuel, Energy Systems, 6 (4), 2015, 507-531, ISSN 18683967.

[25] CAVAllo, A. J.: Hubbert's Petroleum Production Model: An Evaluation and Implications for World Oil Production Forecasts, Natural Resources Research, 4 (13), 2004, 211-221, ISSN 1573-8981. 